\title{
PERBANDINGAN TINGKAT KEBUGARAN, GAMBARAN TINGGI BADAN, BERAT BADAN, SERTA INDEKS MASA TUBUH (IMT) BAGI MAHASISWA PROGRAM STUDI ILMU KEOLAHRAGAAN FIK UNY TAHUN AKADEMIK 2018 DAN 2019
}

\author{
Prijo Sudibjo $^{1}$, Yudik Prasetyo ${ }^{1}$, Sumarjo ${ }^{1}$, Cerika Rismayanthi ${ }^{1}$ \\ ${ }^{1}$ Fakultas Ilmu Keolahragaan, Universitas Negeri Yogyakarta, Jl. Colombo No. 1, Karangmalang Depok, \\ Sleman, Yogyakarta, Indonesia \\ prijo_sudibyo@uny.ac.id,yudik@uny.ac.id, sumarjofik@uny.ac.id, cerika@uny.ac.id
}

\begin{abstract}
Abstrak
Sehat dan bugar adalah dambaan setiap orang. Seseorang yang bugar tidak akan mudah lelah menghadapi kehidupan sehari-hari. Pada penerimaan mahasiswa baru tahun 2018 dilakukan tes keterampilan dan kesehatan, sedangkan pada tahun 2019 tidak ada tes keterampilan dan kesehatan karena calon mahasiswa hanya mengunggah fortofolio dan tes tulus SBMPTN. Hal ini sangat berbeda dirasakan terutama pada mata kuliah gerak dasar yang sedikit mengalami kendala. Sehubungan dengan itu maka sekiranya perlu dilakukan tes keterampilan dan kesehatan pada mahasiswa prodi Ikor angkatan tahun 2019. Hal ini dikarenakan perlu k=kiranya dilakukan uji perbedaan yang dilihat berdasarkan indikator kebugaran fisik, berat badan dan tinggi badan serta Indeks Massa Tubuh. Penelitian ini bertujuan untuk mengetahui Perbandingan Tingkat Kebugaran, Gambaran Tinggi Badan, Berat Badan, Serta Indeks Masa Tubuh (IMT) Bagi Mahasiswa Program Studi Ilmu Keolahragaan FIK UNY Tahun Akademik 2018 Dan 2019. Penelitian ini merupakan Penelitian komparatif dapat berupa komparatif deskriptif (descriptive comparative) maupun komparatif korelasional (correlation comparative). Pengambilan sampel dilakukan dengan teknik consecutive sampling. Rencana penelitian ini dilaksanakan Lapangan Tennis FIK UNY. Instrumen yang digunakan untuk mengumpulkan data adalah. Untuk mengetahui kategori kebugaran jasmani maka data yang berupa waktu tempuh dikonsultasikan dengan tabel penilaian Kebugaran jasmani. Teknik analisis data meliputi: uji normalitas, uji reliabilitas dan uji komparatif.
\end{abstract}

Kata Kunci: Tingkat Kebugaran, Tinggi Badan, Berat Badan, Indeks Masa Tubuh (IMT)

\section{COMPARISON OF FITNESS LEVELS, HEIGHT, WEIGHT, AND BODY MASS INDEX (BMI) FOR THE STUDENTS OF SPORT SCIENCE STUDY PROGRAM FIK UNY ACADEMIC YEAR 2018 AND 2019}

\begin{abstract}
Healthy and fit is everyone's dream. A person who is fit will not be tired of facing everyday life. At the admission of new students in 2018 there will be a skills and health test, while in 2019 there will be no skills and health tests because prospective students only upload the SBMPTN portfolio and sincere tests. This is very different to be felt, especially in basic motion subjects that are slightly constrained. In connection with that, it is necessary to conduct skills and health tests on students of Ikor study program class of 2019. This is because it is necessary to test the differences that are seen based on indicators of physical fitness, weight and height as well as Body Mass Index. This study aims to determine the Comparison of Fitness Levels, Body Height, Weight, and Body Mass Index (BMI) for Students of Sport Science Study Program FIK UNY Academic Year 2018 and 2019. This research is a comparative study in the form of descriptive comparative (descriptive comparative) and correlational comparative
\end{abstract}


MEDIKORA, Vol. XVIII No. 2 Oktober 2019 - 109

Prijo Sudibjo, Yudik Prasetyo, Sumarjo, Cerika Rismayanthi

(correlation comparative). Sampling was done by consecutive sampling technique. The research plan was carried out by the FIK UNY Tennis Court. The instrument used to collect data is. To find out the physical fitness category, the data in the form of travel time is consulted with a physical fitness assessment table. Data analysis techniques include: normality test, reliability test and comparative test. Keywords: Fitness Level, Height, Weight, Body Mass Index (BMI)

\section{PENDAHULUAN}

WHO mendefinisikan kesehatan sebagai keadaan nyaman seutuhnya secara fisik, sosial dan mental, bukan melulu bebas dari penyakit dan cacat atau kekurangan (a state of complete physical, social, and moral well being). Definisi ini hendak melihat kesehatan secara luas dan menyeluruh, bukan hanya dari segi fisik saja melainkan menyangkut eksistensi manusia, inilah definisi WHO jika dilihat dari segi positif. Definisi ini mempunyai kelemahan yakni, dengan merumuskan kesehatan sebagai "keadaan". Dengan demikian peranan aktif dan dinamis manusia sebagai subyek kesehatan itu kurang ditonjolkan. Sadoso (1989: 9) Kebugaran jasmani adalah keadaan atau kemampuan seseorang untuk melakukan aktivitas atau tugas-tugasnya sehari-hari dengan mudah tanpa mengalami kelelahan yang berarti dan masih mempunyai siswa atau cadangan tenaga untuk menikmati waktu senggangnya untuk keperluan-keperluan lainnya. Komponen atau faktor kesegaran jasmani dan komponen kesegaran motorik merupakan satu kesatuan utuh dari komponen kondisi fisik. Agar seseorang dapat dikategorikan kondisi fisiknya baik, maka status komponen-komponennya harus berada dalam kondisi baik pula. Adapun komponen atau faktor jasmani adalah: kekuatan, daya tahan kelenturan.

Kesehatan adalah keadaan sejahtera dari badan, jiwa, dan sosial yang memungkinkan setiap orang hidup produktif secara sosial dan ekonomis. Pemeliharaan kesehatan adalah upaya penaggulangan dan pencegahan gangguan kesehatan yang memerlukan pemeriksaan, pengobatan dan/atau perawatan termasuk kehamilan dan persalinan. Pendidikan kesehatan adalah proses membantu sesorang, dengan bertindak secara sendiri-sendiri ataupun secara kolektif, untuk membuat keputusan berdasarkan pengetahuan mengenai hal-hal yang mempengaruhi kesehatan pribadinya dan orang lain. Definisi yang bahkan lebih sederhana diajukan oleh Larry Green dan para koleganya yang menulis bahwa pendidikan kesehatan adalah kombinasi pengalaman belajar yang dirancang untuk mempermudah adaptasi sukarela terhadap perilaku yang kondusif bagi kesehatan.

Kesehatan Menurut Undang-Undang, dalam Undang-Undang ini yang dimaksud dengan: (1) Kesehatan adalah keadaan sejahtera dari badan, jiwa, dan sosial yang memungkinkan setiap orang hidup produktif secara sosial dan ekonomis. (2) Upaya kesehatan adalah setiap kegiatan untuk memelihara dan meningkatkan kesehatan yang dilakukan oleh pemerintah dan atau masyarakat. (3) Tenaga kesehatan adalah setiap orang yang mengabdikan diri dalam bidang kesehatan serta memiliki pengetahuan dan atau keterampilan melalui pendidikan di bidang kesehatan yang untuk jenis tertentu memerlukan kewenangan untuk melakukan upaya kesehatan. (4) Sarana kesehatan adalah tempat yang digunakan untuk menyelenggarakan upaya kesehatan. Kesehatan adalah sesuatu yang sangat berguna

Olahraga adalah sebuah kata dalam bahasa inggris yang berarti olahraga. Sedang sportif yang merupakan kata sifat yang berarti jujur dan ksatria atau gagah. Dan kata sportivitas yang sebagai kata benda mempunyai arti orang yang melakukan olahraga tersebut (harus) memiliki kejujuran dan sikap ksatria dalam bertindak dan berprilaku saat berolahraga, seperti disiplin, mengikuti ketentuan dan peraturan yang telah ditetapkan atau yang telah disepakati bersama, terutama saat mengikuti suatu pertandingan atau perlombaan olahraga.

Makna olahraga menurut ensiklopedia Indonesia adalah gerak badan yang dilakukan oleh satu orang atau lebih yang merupakan regu atau rombongan. Sedangkan dalam Webster's New Collegiate Dictonary (1980) yaitu ikut serta dalam aktivitas fisik untuk mendapatkan 
kesenangan, dan aktivitas khusus seperti berburu atau dalam olahraga pertandingan (athletic games di Amerika Serikat).

Menurut Cholik Mutohir olahraga adalah proses sistematik yang berupa segala kegiatan atau usaha yang dapat mendorong mengembangkan, dan membina potensi-potensi jasmaniah dan rohaniah seseorang sebagai perorangan atau anggota masyarakat dalam bentuk permainan, perlombaan/pertandingan, dan prestasi puncak dalam pembentukan manusia Indonesia seutuhnya yang berkualitas berdasarkan Pancasila. Untuk penjelasan pengertian olahraga menurut Edward (1973) olahraga harus bergerak dari konsep bermain, games, dan sport. Ruang lingkup bermain mempunyai karakteristik antara lain; a. Terpisah dari rutinitas, b. Bebas, c. Tidak produktif, d. Menggunakan peraturan yang tidak baku. Ruang lingkup pada games mempunyai karakteristik; a. ada kompetisi, b. hasil ditentukan oleh keterampilan fisik, strategi, kesempatan. Sedangkan ruang lingkup sport; permainan yang dilembagakan. Arti olahraga adalah aktivitas untuk melatih tubuh seseorang, tidak hanya secara jasmani tetapi juga rohani, dan bertujuan untuk mencapai prestasi yang setinggi-tingginya.

Menurut undang-undang RI nomor 25 tahun 2000 tentang Pembangunan Nasional, salah satu programnya adalah program pemasyarakatan olahraga dan kebugaran jasmani yang bertujuan untuk meningkatkan kebugaran jasmani masyarakat. Saat ini masyarakat sudah mulai sadar untuk melakukan kegiatan latihan fisik/olahraga melalui berbagai fasilitas olahraga maupun fasilitas umum yang tersedia. Di lain pihak kemajuan ilmu pengetahuan dan teknologi memberikan kemudahan bagi masyarakat dalam bekerja memberi pengaruh yang kurang menguntungkan bagi kesehatan, pemanfaatan anggota tubuh dalam melaksanakan aktivitas sehari-hari kurang sehingga tingkat kebugaran jasmaninya menjadi rendah.Upaya-upaya untuk berolahraga sebagai sarana meningkatkan derajat kesehatan dan kebugaran jasmani masyarakat telah dikembangkan didaerah-daerah yang potensial.

Indeks Massa Tubuh (IMT) digunakan sebagai parameter status gizi dengan membandingan antara berat badan dalam kilogram dengan tinggi badan dalam meter kuadrat. IMT adalah ukuran yang saat ini digunakan untuk menentukan antropometri tinggi atau berat badan orang dewasa dan untuk mengklasifikasikan ke dalam norma kelompok yang sudah ditetapkan. Badan kesehatan dunia telah menggolongkan kategori indeks massa tubuh menjadi 4 golongan, yaitu : kurus, normal, kelebihan berat badan dan obesitas.

Seseorang yang mempunyai jasmani sehat belum tentu mempunyai status kebugaran yang baik. Seseorang yang mempunyai berat badan ideal belum tentu juga mempunyai kebugaran yang bagus. Karena untuk menentukan status kebugaran jasmani seseorang tidak dapat hanya dilihat dari fisiknya saja, tetapi harus dilakukan tes pengukuran kebugaran jasmani.

\section{METODE}

Penelitian ini adalah penelitian komparatif tentang perbedaan tingkat kebugaran, gambaran tinggi badan dan berat badan serta indeks masa tubuh. Metode yang digunakan dalam penelitian ini adalah metode survei dengan teknik tes dan pengukuran. Metode survei merupakan metode penelitian yang bertujuan untuk mengetahui status fenomena dan untuk menentukan kesamaan status dengan cara membandingkan standar, norma, dan kriteria yang sudah ditentukan (Zainal Arifin, 2012: 42). Peneliti ini bertujuan untuk mengetahui perbedaan tingkat kebugaran, gambaran tinggi badan dan berat badan serta indeks masa tubuh pada mahasiswa Prodi IKOR tahun akademik 2018 dan 2019.

Populasi adalah wilayah generalisasi yang terdiri atas objek atau subjek yang mempunyai kualitas dan karakteristik tertentu yang ditetepkan olah penelitiuntuk dipelajari dan kemudian ditarik kesimpulan (Sugiyono, 2013: 117). Populasi dalam penelitian ini adalah Seluruh mahasiswa Prodi Ilmu Keolahragaan FIK UNY angkatan 2018-2019 yang berjumlah 110 orang. 
Sampel adalah sebagian dari jumlah dan karakteristik yang dimiliki oleh populasi tersebut. Apabila populasi besar dan peneliti tidak mungkin mempelajari yang ada pada populasi maka peneliti dapat mengunakan sampel yang diambil dari populasi itu (Sugiyono, 2013: 117). Sampel yang digunakan dalam penelitian ini adalah Mahasiswa Prodi ilmu Keolahragaan yang diterima melalui jalur SBMPTN tahun akademik 2018-2019 yang berjumlah 40 orang.

Lokasi Penelitian ini dilakukan di Lapangan Tennis Indoor dan Stadion Atletik FIK UNY. Pengambilan data dilakukan pada bulan Oktober sampai Desember 2019.

Metode pengambilan data merupakan alat atau fasilitas yang digunakan oleh peneliti dalam mengumpulkan data agar pekerjaannya lebih mudah dan hasilnya lebih baik, dalam arti lebih cermat, lengkap, dan sistematis sehingga lebih mudah diolah (Arikunto, 2006: 160). Dalam penelitian ini peneliti menggunakan tes. Untuk memperoleh data dalam penelitian ini digunakan metode yang sesuai dengan tujuan penelitian ini yaitu ingin mengetahui perbandingan kebugaran jasmani. Berikut rangkaian tes keterampilan motorik terdiri dari enam (6) item tes yang tersaji pada tabel berikut:

Tabel 1. Lempar tangkap bola ke dinding (wall pass)

Norma Penilaian Lempar Tangkap Bola Tennis

(Jumlah ulangan)

\begin{tabular}{|l|c|c|}
\hline \multicolumn{1}{|c|}{ Kategori } & Putra & Putri \\
\hline Sangat Baik & $>35$ & $>30$ \\
\hline Baik & $30-35$ & $25-30$ \\
\hline Sedang & $25-29$ & $20-24$ \\
\hline Kurang & $20-24$ & $15-19$ \\
\hline Sangat Kurang & $<20$ & $<15$ \\
\hline
\end{tabular}

(Sumber : Pusat Kesegaran Jasmani, Depdikbud, 1996)

Tabel 2. Lompat tegak (vertical jump)

\begin{tabular}{|l|c|c|}
\hline \multicolumn{1}{|c|}{ Kategori } & Putra & Putri \\
\hline Sangat Baik & $>72$ & $>49$ \\
\hline Baik & $60-72$ & $39-49$ \\
\hline Sedang & $50-59$ & $31-38$ \\
\hline Kurang & $39-49$ & $23-30$ \\
\hline Sangat Kurang & $<39$ & $<23$ \\
\hline
\end{tabular}

Sumber : Pusat Kesegaran Jasmani, Depdikbud, $1996 *$ (dalam satua cm) 
MEDIKORA, Vol. XVIII No. 2 Oktober 2019 - 112

Prijo Sudibjo, Yudik Prasetyo, Sumarjo, Cerika Rismayanthi

Tabel 3. Sit Up 60 detik

Norma Penialaian Sit-Up

(Jumlah Ulangan)

\begin{tabular}{|l|c|c|}
\hline \multicolumn{1}{|c|}{ Kategori } & Putra & Putri \\
\hline Sangat Baik & $>41$ & $>28$ \\
\hline Baik & $30-41$ & $20-28$ \\
\hline Sedang & $21-29$ & $10-19$ \\
\hline Kurang & $10-20$ & $3-9$ \\
\hline Sangat Kurang & $<10$ & $<3$ \\
\hline
\end{tabular}

Sumber : Pusat Kesegaran Jasmani, Depdikbud, 1996

Tabel 4. Push Up 60 detik

Norma Penilaian Push Up

(Jumlah Ulangan)

\begin{tabular}{|l|c|c|}
\hline \multicolumn{1}{|c|}{ Kategori } & Putra & Putri \\
\hline Sangat Baik & $>46$ & $>35$ \\
\hline Baik & $36-46$ & $25-25$ \\
\hline Sedang & $26-35$ & $15-24$ \\
\hline Kurang & $16-25$ & $5-14$ \\
\hline Sangat Kurang & $<16$ & $<5$ \\
\hline
\end{tabular}

Sumber : Pusat Kesegaran Jasmani, Depdikbud, 1996

Tabel 5. Illinois Agility Run Test

Norma Penilaian Tes Kelincahan

(waktu dalam detik)

\begin{tabular}{|l|c|c|}
\hline \multicolumn{1}{|c|}{ Kategori } & Putra & Putri \\
\hline Sangat Baik & $<15.2$ & $<17.0$ \\
\hline Baik & $15.2-16.1$ & $17.0-17.9$ \\
\hline Sedang & $16.2-18.1$ & $18.0-21.7$ \\
\hline Kurang & $18.2-18.3$ & $21.8-23.0$ \\
\hline Sangat Kurang & $>18.3$ & $>23.0$ \\
\hline
\end{tabular}

Sumber : Brian Mackenzie, 2005 
MEDIKORA, Vol. XVIII No. 2 Oktober 2019 - 113

Prijo Sudibjo, Yudik Prasetyo, Sumarjo, Cerika Rismayanthi

Tabel 6. Lari $1600 \mathrm{~m}$.

Norma Penilaian tes lari $1600 \mathrm{~m}$

(waktu dalam menit)

\begin{tabular}{|l|c|c|}
\hline \multicolumn{1}{|c|}{ Kategori } & Putra & Putri \\
\hline Sangat Baik & $<15.2$ & $<17.0$ \\
\hline Baik & $15.2-16.1$ & $17.0-17.9$ \\
\hline Sedang & $16.2-18.1$ & $18.0-21.7$ \\
\hline Kurang & $18.2-18.3$ & $21.8-23.0$ \\
\hline Sangat Kurang & $>18.3$ & $>23.0$ \\
\hline
\end{tabular}

(Sumber: Morrow, Jackson, Disch \& mood, 2000)

\section{Analisis data}

Teknik Analisis Data Analisis data adalah proses penyederhanaan data ke dalam bentuk yang lebih mudah dibaca dan diinterpretasikan (Masri Singarimbun dan Sofian Effendi, 2008: 263). Analisis data dalam penelitian ini dilakukan dengan cara statistik deskriptif kuantitatif. Menurut Sugiyono (2011: 199), statistik deskriptif adalah statistik yang digunakan untuk menganalisis data dengan cara mendeskripsikan atau menggambarkan data yang telah dikumpulkan sebagaimana adanya tanpa bermaksud membuat kesimpulan yang berlaku untuk umum atau generalisasi. Analisis deskriptif berfungsi menerangkan keadaan gejala atau personal sehingga penyajian data penelitian akan mudah dipahami. Teknis data yang digunakan pada penelitian ini adalah uji $t$ dengan taraf signifikasi 5\%. Menurut Sugiono (2006: 119) rumus yang digunakan dalam uji t adalah sebagai berikut:

$$
\mathrm{t}=\frac{X_{1}-X_{2}}{\overline{\frac{S_{1}^{2}}{n_{1}}+\frac{S_{2}^{2}}{n_{2}}-2 r \frac{S_{1}}{\overline{n_{1}}}} \frac{S_{2}}{\overline{n_{2}}}}
$$

Keterangan:

$X_{1} \quad$ : rata-rata sampel 1

$X_{2} \quad$ : rata-rata sampel 2

$\mathrm{S}_{1} \quad$ : simpangan baku sampel 1

$\mathrm{S}_{2} \quad$ : simpangan baku sampel 2

$S^{2}{ }_{1} \quad$ : varian sampel 1

$S_{2}^{2} \quad$ : varian sampel 2

$\mathrm{r} \quad$ : korelasi antara dua sampel

Sebelum dilakukan uji t maka dilakukan uji prasyarat yaitu uji normalitas data.Uji normalitas dicari dengan rumus kai kuadrat, yaitu untuk mengetahui apakah gejla-gejala yang diteliti mempunyai distribusi normal atau tidak. Menurut Sutrisno Hadi (2004: 259) rumus yang digunakan adalah sebagai berikut: 
MEDIKORA, Vol. XVIII No. 2 Oktober 2019 - 114

Prijo Sudibjo, Yudik Prasetyo, Sumarjo, Cerika Rismayanthi

$$
\mathrm{X}^{2}=\frac{f_{\mathrm{o}}-f_{h}^{2}}{f_{h}}
$$

Keterangan :

$\mathrm{X}^{2} \quad$ : Chi kuadrat

F。 : Frekuensi yang diperoleh dari (diobservasi dalam) sampel.

$\mathrm{f}_{\mathrm{b}} \quad$ : Frekuensi yang diharapkan dalam sampel

\section{HASIL DAN PEMBAHASAN}

Sampel dalam penelitian ini adalah mahasiswa IKOR 2018 dan 2019 yang yang diterima melalui jalur SBMPTN. Sampel mahasiswa IKOR tahun angkatan 2018 sejumlah 15 mahasiswa yang semuanya laki-laki, sedangkan sampel mahasiswa IKOR tahun angkatan 2019 sejumlah 14 mahasiswa yang terdiri atas 10 laki-laki dan 4 perempuan. Seluruh data deskriptif hasil item penelitian yang meliputi: push up, sit up, vertical jump, wall pass, kelincahan dan lari 1600 meter dipaparkan dalam tabel-tabel di bawah ini.

Tabel 7. Kategorisasi Push Up Mahasiswa IKOR 2018 dan 2019

\begin{tabular}{|c|l|c|c|c|c|}
\hline \multirow{2}{*}{ No. } & \multirow{2}{*}{ Kategori } & \multicolumn{2}{|c|}{ IKOR 2018 } & \multicolumn{2}{c|}{ IKOR 2019 } \\
\cline { 3 - 6 } & Jumlah (n) & Persentase (\%) & Jumlah (n) & Persentase (\%) \\
\hline 1. & sangat kurang & 1 & 6.7 & 1 & 7.1 \\
\hline 2. & kurang & 7 & 46.7 & 7 & 50.0 \\
\hline 3. & sedang & 5 & 33.3 & 6 & 42.9 \\
\hline 4. & baik & - & - & - & - \\
\hline 5. & sangat baik & 2 & 13.3 & - & - \\
\hline total & & 15 & 100.0 & 14 & 100 \\
\hline
\end{tabular}

틀 IKOR 2018 틀 IKOR 2019

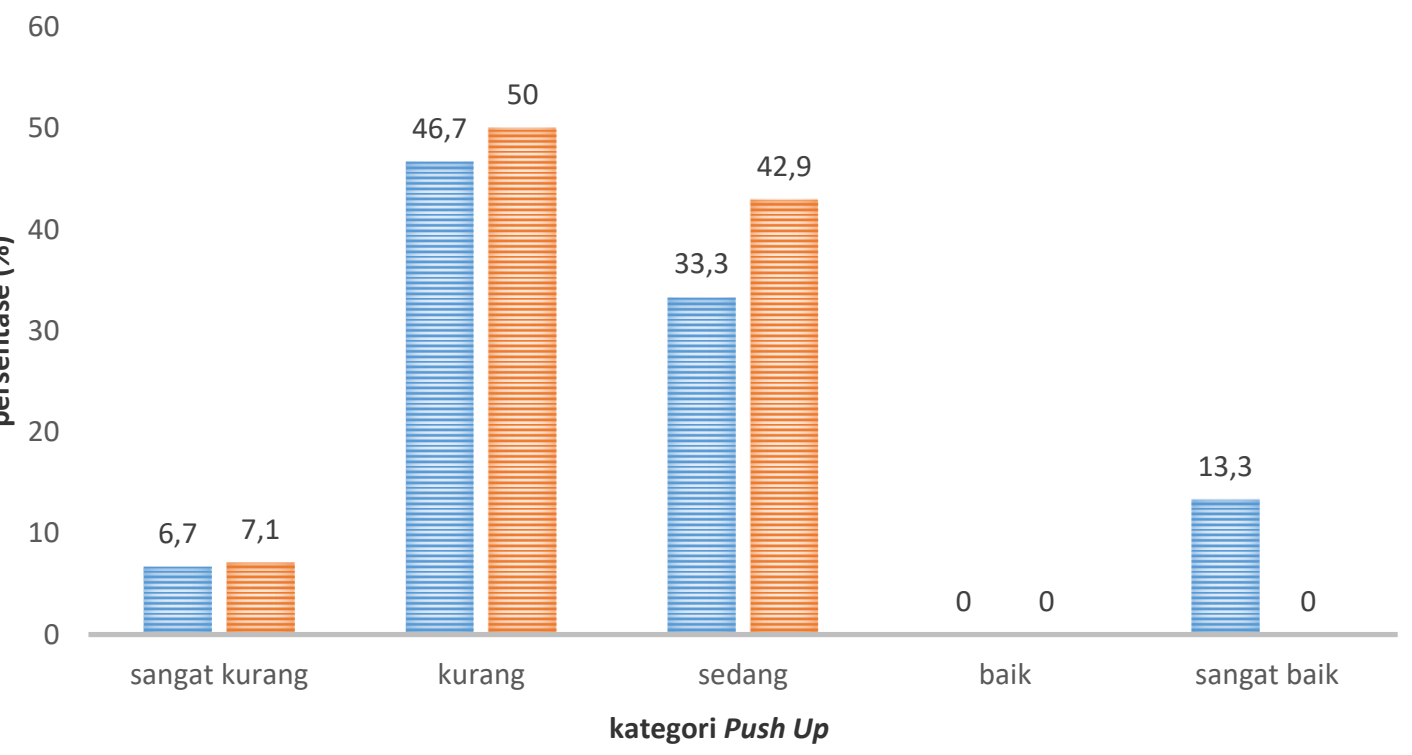

Gambar 1. Perbandingan Hasil Capaian Push Up Mahasiswa IKOR 2018 dan 2019

Tabel 7 di atas menunjukkan hasil push up mahasiswa IKOR tahun angkatan 2018 dan 2019. Data menunjukkan sebagian besar kategorisasi push up baik mahasiswa IKOR 2018 
ataupun 2019 berada pada kategori kurang, dengan persentase kategori kurang mahasiswa IKOR 2018 sebesar 46.7\% dan IKOR $201950 \%$.

Hasil tes ketrampilasn sit up menunjukkan hasil yang berbeda dengan push up. Mahasiswa IKOR 2018 dan 2019 menunjukkan hampir semua mahasiswa memiliki kategori sit up yang sangat baik. Hal tersebut dapat dilihat pada tabel 8 dan gambar 2 di bawah ini dengan persentase mahasiswa IKOR 2018 sebesar $80 \%$ dan IKOR 2019 sebesar 92,9\%.

Tabel 8. Kategorisasi Sit up Mahasiswa IKOR 2018 dan 2019

\begin{tabular}{|c|l|c|c|c|c|}
\hline \multirow{2}{*}{ No. } & \multirow{2}{*}{ Kategori } & \multicolumn{2}{|c|}{ IKOR 2018 } & \multicolumn{2}{c|}{ IKOR 2019 } \\
\cline { 3 - 6 } & Jumlah (n) & Persentase (\%) & Jumlah (n) & Persentase (\%) \\
\hline 1. & sangat kurang & - & - & - & - \\
\hline 2. & kurang & - & - & - & - \\
\hline 3. & sedang & 1 & 6.7 & - & - \\
\hline 4. & baik & 2 & 13.3 & 1 & 7.1 \\
\hline 5. & sangat baik & 12 & 80.0 & 13 & 92.9 \\
\hline total & 15 & 100.0 & 14 & 100 \\
\hline
\end{tabular}

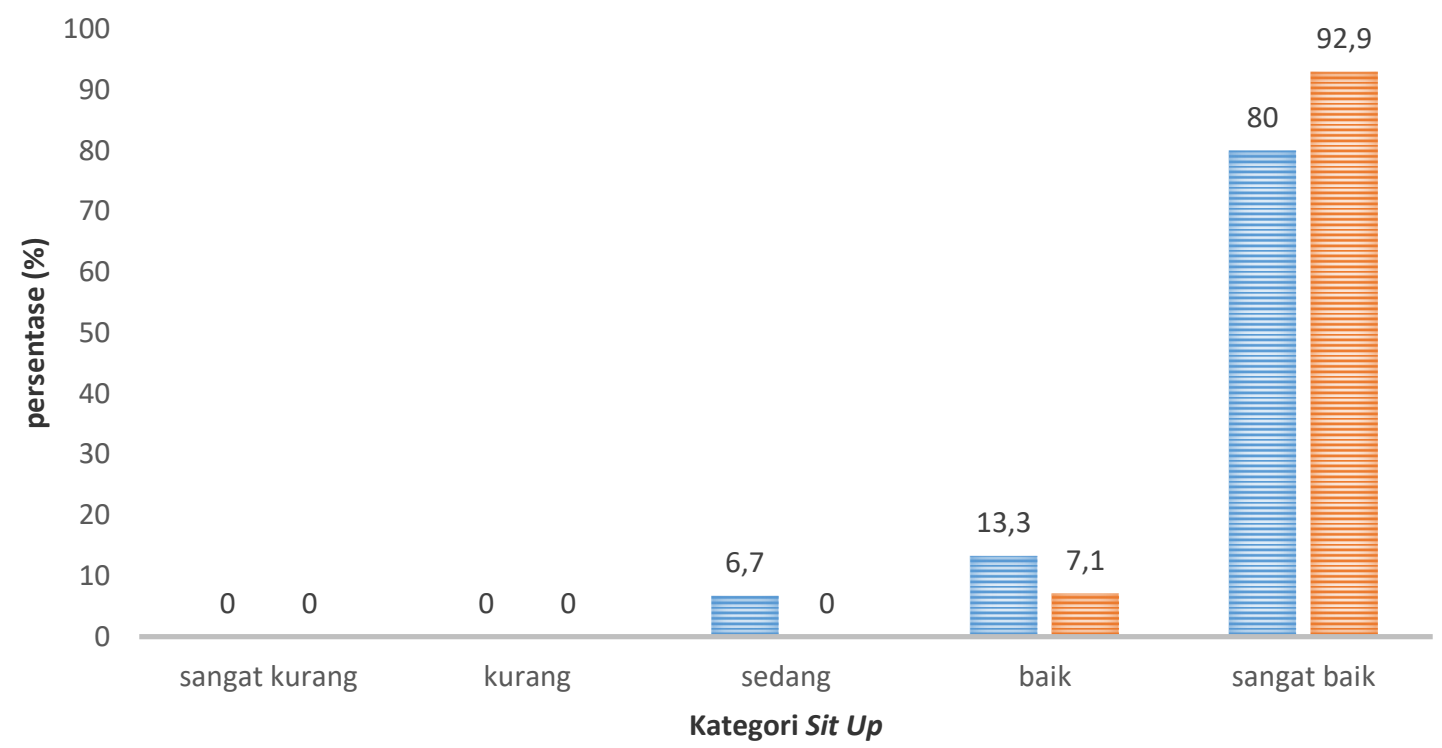

Gambar 2. Perbandingan Hasil Capaian Sit Up Mahasiswa IKOR 2018 dan 2019

Tabel 9 dan gambar 3 di bawah ini menunjukkan hasil tes ketrampilan vertical jump mahasiswa IKOR 2018 dan 2019. Data menunjukkan hasil yang beragam pada mahasiswa IKOR 2018 dan 2019 dengan kisaran kategori sedang dan baik. Pada mahasiswa IKOR 2018 sejumlah $80 \%$ tercatat memiliki kategori yang baik sedangkan pada mahasiswa IKOR 2019 lebih dari separuh berada pada kategori sedang dengan persentase $57,1 \%$. 
MEDIKORA, Vol. XVIII No. 2 Oktober 2019 - 116

Prijo Sudibjo, Yudik Prasetyo, Sumarjo, Cerika Rismayanthi

Tabel 9. Kategorisasi Vertical Jump Mahasiswa IKOR 2018 dan 2019

\begin{tabular}{|c|l|c|c|c|c|}
\hline \multirow{2}{*}{ No. } & \multirow{2}{*}{ Kategori } & \multicolumn{2}{|c|}{ IKOR 2018 } & \multicolumn{2}{c|}{ IKOR 2019 } \\
\cline { 3 - 6 } & Jumlah (n) & Persentase (\%) & Jumlah (n) & Persentase (\%) \\
\hline 1. & sangat kurang & - & - & - & - \\
\hline 2. & kurang & - & - & - & - \\
\hline 3. & sedang & 3 & 20.0 & 8 & 57.1 \\
\hline 4. & baik & 12 & 80.0 & 6 & 42.9 \\
\hline 5. & sangat baik & - & - & - & - \\
\hline total & & 15 & 100.0 & 14 & 100 \\
\hline
\end{tabular}

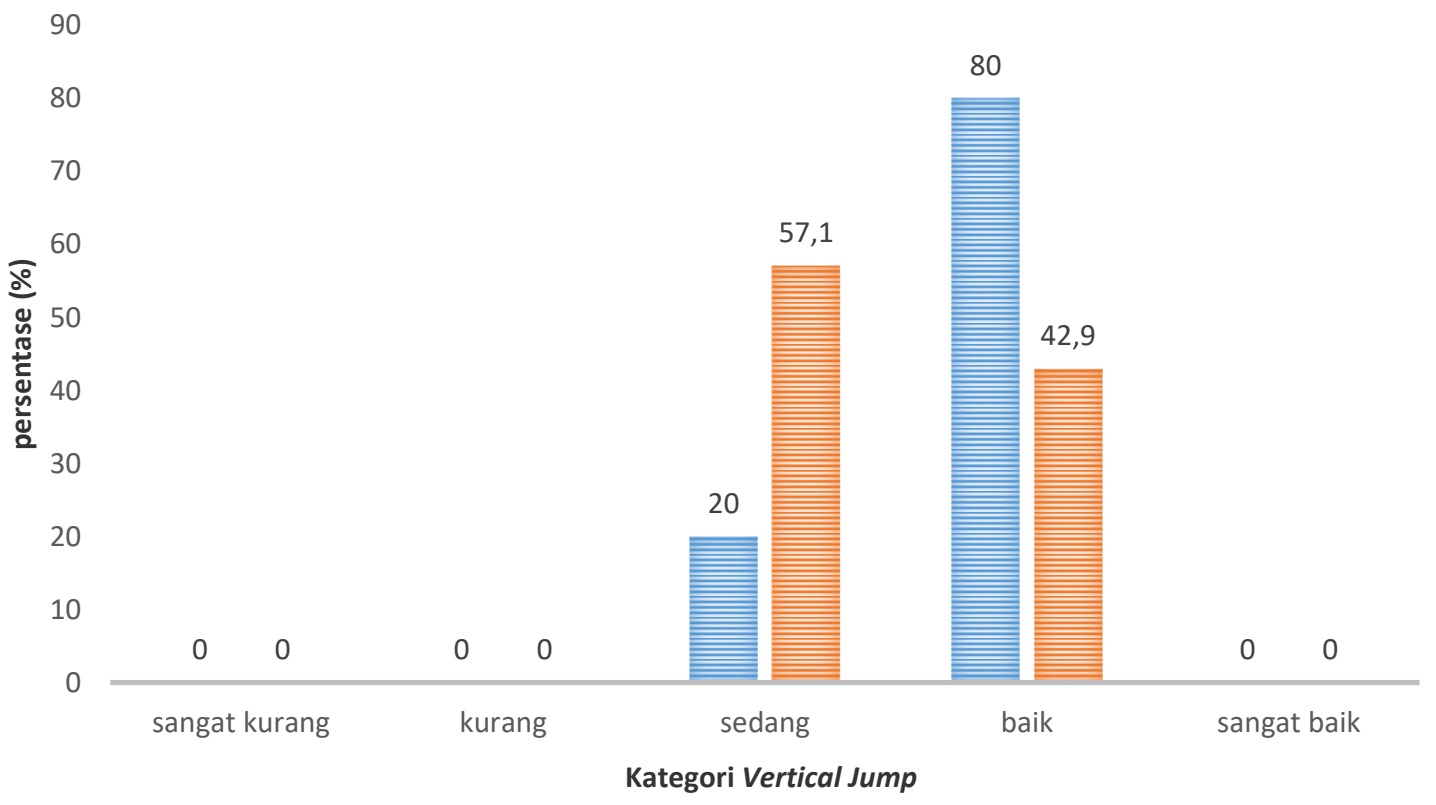

Gambar 3. Perbandingan Hasil Capaian Vertical Jump Mahasiswa IKOR 2018 dan 2019

Uji ketrampilan wall pass mahasiswa IKOR 2018 dan 2019 menunjukkan hasil yang beragam namun tidak ada yang mendapatkan kategori sangat baik pada kedua angkatan. Hasil tersebut dapat dilihat pada tabel 10 dan gambar 4 di bawah ini. Pada mahasiswa IKOR 2018 data menunjukkan mahasiswa yang dikategorikan kurang sebesar $26.7 \%$, sedang $46.7 \%$ dan baik 26.7\% . pada mahasiswa IKOR 2019 mahasiswa yang dikategorikan sangat kurang sebesar $42.9 \%$, kurang $50 \%$ dan baik $7.1 \%$

Tabel 10. Kategorisasi Wall Pass Mahasiswa IKOR 2018 dan 2019

\begin{tabular}{|c|l|c|c|c|c|}
\hline \multirow{2}{*}{ No. } & \multirow{2}{*}{ Kategori } & \multicolumn{2}{|c|}{ IKOR 2018 } & \multicolumn{2}{c|}{ IKOR 2019 } \\
\cline { 3 - 6 } & Jumlah (n) & Persentase (\%) & Jumlah (n) & Persentase (\%) \\
\hline 1. & sangat kurang & - & - & 6 & 42.9 \\
\hline 2. & kurang & 4 & 26.7 & 7 & 50.0 \\
\hline 3. & sedang & 7 & 46.7 & - & - \\
\hline 4. & baik & 4 & 26.7 & 1 & 7.1 \\
\hline 5. & sangat baik & - & - & - & - \\
\hline total & & 15 & 100.0 & 14 & 100 \\
\hline
\end{tabular}


MEDIKORA, Vol. XVIII No. 2 Oktober 2019 - 117

Prijo Sudibjo, Yudik Prasetyo, Sumarjo, Cerika Rismayanthi

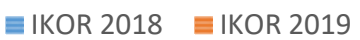

60

50

50

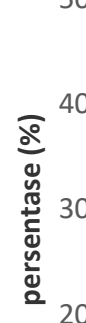

42,9

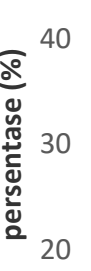

10

0
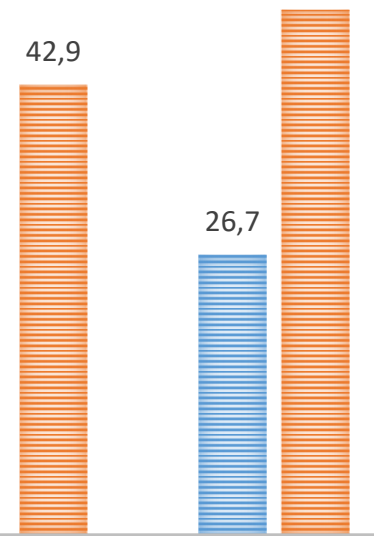

46,7

sangat kurang

kurang

sedang

Kategori Wall Pass

Gambar 4. Perbandingan Hasil Capaian Wall Pass Mahasiswa IKOR 2018 dan 2019

Tabel 11 dan diagram 5 di bawah menunjukkan hasil uji kelincahan mahasiswa IKOR 2018 dan 2019. Data menunjukkan sebagian besar hasil berada pada kategori sedang dengan persentase mahasiswa IKOR 2018 sebesar 66.7\% dan IKOR 2019 sebesar 85.7\%.

Tabel 11. Kategorisasi Kelincahan Mahasiswa IKOR 2018 dan 2019

\begin{tabular}{|c|l|c|c|c|c|}
\hline \multirow{2}{*}{ No. } & \multirow{2}{*}{ Kategori } & \multicolumn{2}{|c|}{ IKOR 2018 } & \multicolumn{2}{c|}{ IKOR 2019 } \\
\cline { 3 - 6 } & & Jumlah (n) & Persentase (\%) & Jumlah (n) & Persentase (\%) \\
\hline 1. & sangat kurang & - & - & 1 & 7.1 \\
\hline 2. & kurang & 3 & 20.0 & 1 & 7.1 \\
\hline 3. & sedang & 10 & 66.7 & 12 & 85.7 \\
\hline 4. & baik & 1 & 6.7 & - & - \\
\hline 5. & sangat baik & 1 & 6.7 & - & - \\
\hline total & & 15 & 100.0 & 14 & 100 \\
\hline
\end{tabular}


MEDIKORA, Vol. XVIII No. 2 Oktober 2019 - 118

Prijo Sudibjo, Yudik Prasetyo, Sumarjo, Cerika Rismayanthi

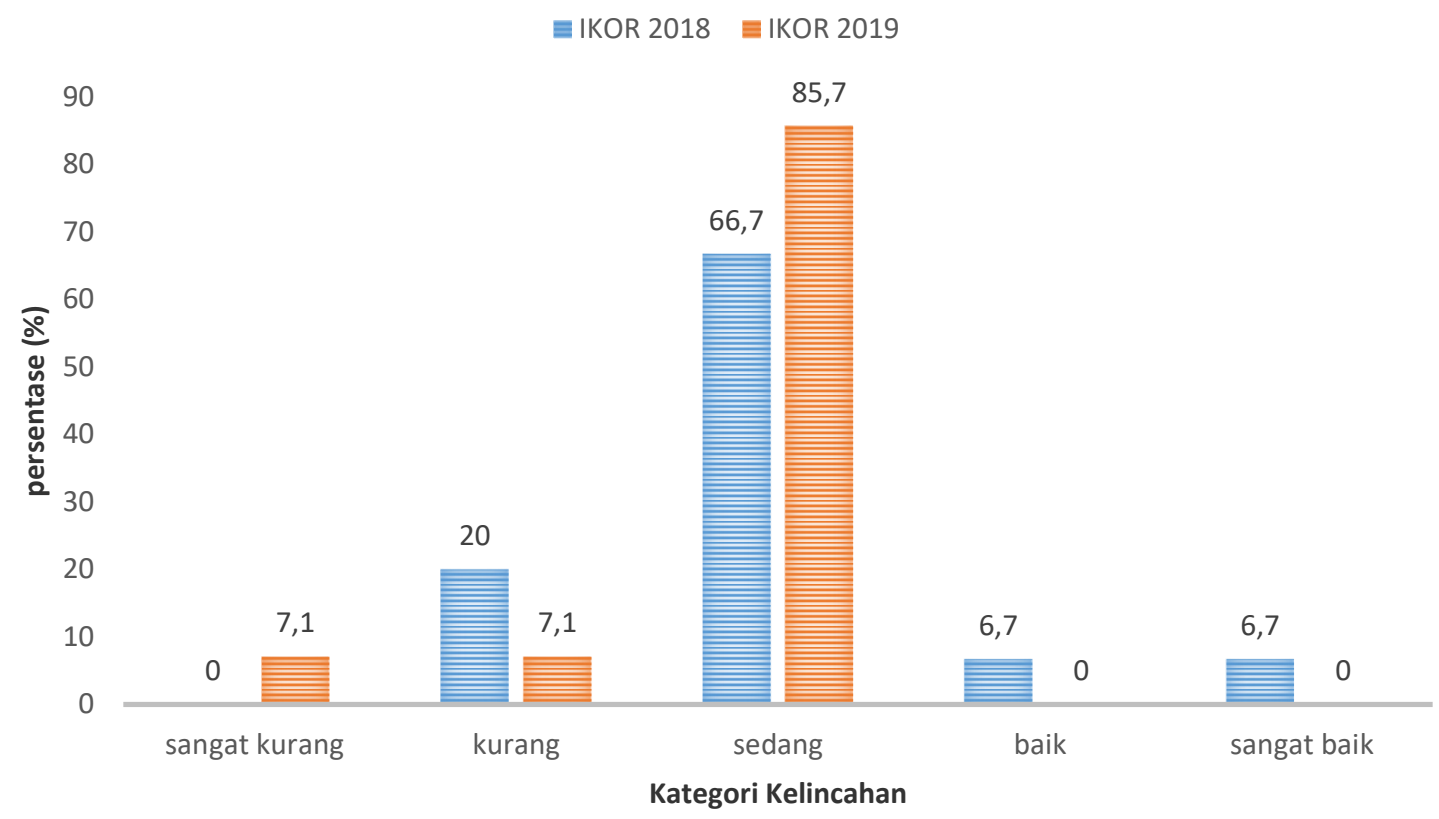

Gambar 5. Perbandingan Hasil Capaian Uji Kelincahan Mahasiswa IKOR 2018 dan 2019

Tabel 12. Kategorisasi Lari 1600m Mahasiswa IKOR 2018 dan 2019

\begin{tabular}{|c|l|c|c|c|c|}
\hline \multirow{2}{*}{ No. } & \multirow{2}{*}{ Kategori } & \multicolumn{2}{|c|}{ IKOR 2018 } & \multicolumn{2}{c|}{ IKOR 2019 } \\
\cline { 3 - 6 } & & Jumlah (n) & Persentase (\%) & Jumlah (n) & Persentase (\%) \\
\hline 1. & sangat kurang & 2 & 13.3 & 2 & 14.3 \\
\hline 2. & kurang & 2 & 13.3 & 5 & 35.7 \\
\hline 3. & sedang & 4 & 26.7 & 6 & 42.9 \\
\hline 4. & baik & 6 & 40.0 & 1 & 7.1 \\
\hline 5. & sangat baik & 1 & 6.7 & - & - \\
\hline total & 15 & 100.0 & 14 & 100 \\
\hline
\end{tabular}

틀 IKOR 2018 틀 IKOR 2019

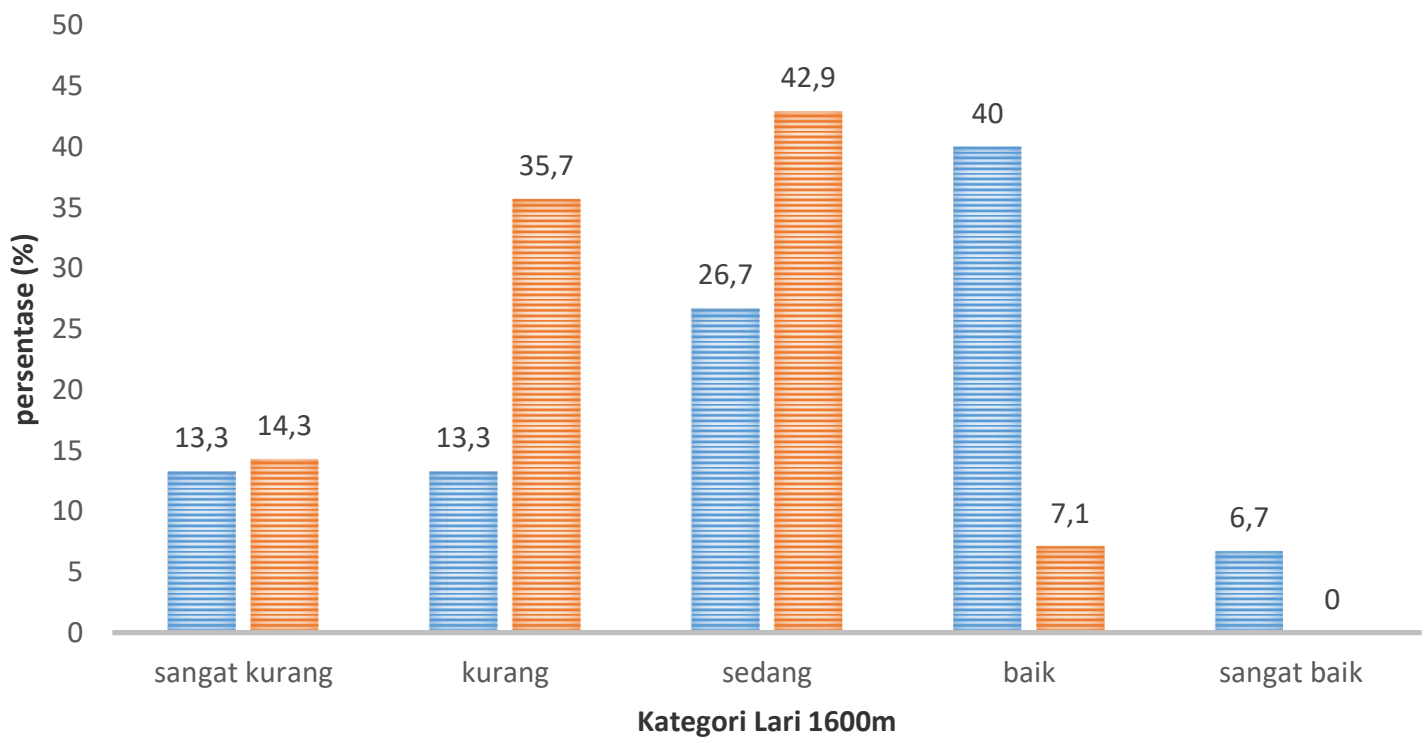

Gambar 6. Perbandingan Hasil Capaian lari 1600 meter Mahasiswa IKOR 2018 dan 2019 
Hasil uji keterampilan lari 1600 meter menunjukkan hasil yang bervariatif, hampir semua kategori memiliki persentase kecuali pada mahasiswa IKOR 2019 tidak ada yang mampu mencapai kategori sangat baik. Data terkait uji keterampilan lari 1600 meter mahasiswa IKOR 2018 dan 2019 disajikan pada tabel dan diagram 6 di atas.

Uji komparatif yang digunakan untuk mengolah data penelitian ini adalah Uji MannWhitney dikarenakan kelompok yang diujikan merupakan dua kelompok tidak berpasangan dimana distribusinya tidak normal. Hasil uji komparatif dapat dilihat pada tabel di bawah ini:

Tabel 13. Test Statistics ${ }^{\mathrm{b}}$

\begin{tabular}{|l|r|r|r|r|r|r|}
\hline & Push Up & \multicolumn{1}{c|}{ Sit Up } & Vertica Jump & Wall Pass & Kelincahan & Lari 1600m \\
\hline Mann-Whitney U & 95.000 & 91.000 & 66.000 & 27.000 & 97.500 & 64.000 \\
Wilcoxon W & 200.000 & 211.000 & 171.000 & 132.000 & 202.500 & 169.000 \\
Z & -.478 & -1.020 & -2.024 & -3.552 & -.437 & -1.856 \\
Asymp. Sig. (2-tailed) & .633 & .308 & .043 & .000 & .662 & .063 \\
Exact Sig. [2*(1-tailed & $.683^{\mathrm{a}}$ & $.561^{\mathrm{a}}$ & $.093^{\mathrm{a}}$ & $.000^{\mathrm{a}}$ & $.747^{\mathrm{a}}$ & $.077^{\mathrm{a}}$ \\
Sig.)] & & & & & \\
\hline
\end{tabular}

Dari tabel di atas di dapatkan hasil bahwa hanya pada uji keterampilan wall pass saja yang memiliki perbedaan yang bermakna antara mahasiswa IKOR 2018 dan 2019, dengan nilai $\mathrm{p}=0,000(\mathrm{p}<0,05)$ yang menandakan bahwa terdapat perbedaan yang bermakna antara dua variabel yang diujikan. Sedangkan pada variabel yang lain menunjukkan semua nilai $p>0,05$ yang menandakan bahwa tidak ada perbedaan yang signifikan.

Data statistik menunjukkan hanya uji keterampilan wall pass saja yang memiliki perbedaan yang bermakna antara mahasiswa IKOR 2018 dan 2019. Nilai signifikasi pada uji keterampilan wall pass menunjukkan nilai $\mathrm{p}=0,000(\mathrm{p}<0,05)$ yang menandakan bahwa terdapat perbedaan yang bermakna antara dua variabel yang diujikan. Sedangkan pada item penilaian lain menunjukkan nilai signifikansi $\mathrm{p}>0,05$ yang menandakan bahwa tidak ada perbedaan yang bermakna antara mahasiswa IKOR 2018 dan 2019. Hal ini disebabkan karena jumlah sampel yang terlalu kecil. Meskipun dalam uji statistik tidak terdapat perbedaan yang bermakna pada hamper seluruh item penilaian, tetapi dari persentase menunjukkan adanya perbedaan dari setiap item test.

\section{SIMPULAN}

Berdasarkan hasil penelitian dan pembahasan yang telah dipaparkan maka dapat diambil kesimpulan bahwa hanya uji keterampilan wall pass saja yang memiliki perbedaan yang bermakna antara mahasiswa IKOR 2018 dan 2019. Nilai signifikasi pada uji keterampilan wall pass menunjukkan nilai $\mathrm{p}=0,000(\mathrm{p}<0,05)$ yang menandakan bahwa terdapat perbedaan yang bermakna antara dua variabel yang diujikan. Sedangkan pada item penilaian lain menunjukkan nilai signifikansi $\mathrm{p}>0,05$ yang menandakan bahwa tidak ada perbedaan yang bermakna antara mahasiswa IKOR 2018 dan 2019.

\section{DAFTAR PUSTAKA}

Cooper, K.H. (1994). Antioxidant Revolution. Thomas Nelson Publishers, Nashville-AtlantaLondon-Vancauver.

Depdiknas, (2000). Pedoman dan Modul Palatihan Kesehatan Olahraga bagi pelatih Olahragawan Pelajar. Pusat Pengembangan Kualitas Jasmani: Depdiknas

Dinkes. (1986). Manual Kesehatan Olahraga. Jakarta: Dinas Kesehatan. 
Giriwijoyo, H.Y.S.S. (1992). Ilmu Faal Olahraga. Bandung: Buku Perkuliahan Mahasiswa FPOK-IKIP.

Giriwijoyo, H.Y.S.S. dan H.Muchtamadji M.Ali (1997). Makalah: Pendidikan Jasmani dan Olahraga, Fakultas Pendidikan Olahraga dan Kesehatan, IKIP Bandung.

Giriwijoyo, H.Y.S.S. dan H. Muchtamadji M. Ali (1999). Makalah: Pendidikan Jasmani dan Olahraga di Sekolah, Fakultas Pendidikan Olahraga dan Kesehatan, IKIP Bandung

Giriwijoyo, H.Y.S.S. (2000). Olahraga Kesehatan. Bandung: Bahan Perkuliahan Mahasiswa FPOK-UPI.

Sadoso Sumosardjuno, (1988). Pengetahuan Praktis dalam Olahraga. Jakarta: PT. Gramedia. Sadoso Sumosardjuno, (1986). Manual Kesehatan Olahraga. Jakarta: Dinas Kesehatan. 